\title{
Przegląd książek/Dyskusje
}

DOI : $10.14746 /$ pp.2017.22.4.16

\section{Bartlomiej Zdaniuk, Konsolidacja państwa w Republice Moldawii, published by University of Warsaw, Warsaw 2016, pp. 282.}

The monograph entitled Konsolidacja państwa w Republice Mołdawii [State Consolidation in the Republic of Moldova], was published in 2016. Its author is dr hab. Bartłomiej Zdaniuk (PhD $)^{1}$ - an employee of the Faculty of Journalism and Political Science at the University of Warsaw. The book consists of 4 chapters, introduction, conclusion, annexes, bibliography, and (something that deserves attention and which should become a publishing practice) a list of contents and abstracts in congressional languages, and those specific to the research area (English, French, Romanian and Russian). The monograph consists of 282 pages of material reviewed by three independent experts, including a representative of a foreign research center.

The author of the monograph refers to a very interesting issue - the problem of state cohesion in the Republic of Moldova (RM), building a theoretical basis for the argument of the concept of "consolidation," understood as "fixing the established political system" (p. 17). Until now, in the literature on the subject, the concept of consolidation was most often associated with democracy, and the statement "consolidation of democracy" has become quite popular. Such terminology applies to stable democracies, where political processes are based on rivalry - not political struggle. As we can read in the monograph: "In many countries, the problem is not only the consolidation of democracy, but the consolidation of the state in general" (pp. 17-18). Thus, in the case of selected countries of Eastern and South-East Europe, the Caucasus or Central Asia, the term "state consolidation" as used by the author is more appropriate. Bartłomiej Zdaniuk has attempted to structure the "conceptual grid of the processes of state consolidation" (p. 18), and the Republic of Moldova became the case study on the basis of which the author has created the model (p. 19). As Bartłomiej Zdaniuk points out in his publication, the state has little experience in the field of the "art of government" (p. 91). The author's ambition was to not to confront the definition of consolidation with democracy, but with the state (p. 83). Importantly, the consolidation of the state is discussed as a process rather than the description of its perfect condition (p. 88).

Professor Janusz Solak, describing the Republic of Moldova, drew attention to the basic fact that it was a "republic split into three" (Solak, 2009), thus highlighting the apparent split of both the territory and the nation. In addition, he stressed the importance of Transnistria in a centerperiphery relationship, pointing out the historical, social, military and geopolitical aspect of the conflict which has continued uninterrupted since the 1990s. Most of the researchers dealing with Moldovan issues focus primarily on the phenomenon of Transnistrian separatism (Oleksy, 2016). The author of the reviewed monograph highlights the fundamental question: "The main challenges for the consolidation of the state of the Republic of Moldova concern primarily the «main» part of the territory of the state. The Gagauzian issue and, paradoxically, even more the Transnistrian seems to be of a secondary character" (p. 19). The above statement can be considered as one of the main theses of the reviewed monograph, and the author begins his further considerations by setting out 5 major and 14 detailed hypotheses of his research (pp. 21-22).

${ }^{1}$ On 15 September 2017, dr hab. Bartłomiej Zaniuk was nominated Polish ambassador to the Republic of Moldova. 
In Chapter I (pp. 37-91), the author discusses the notion of consolidation in political science by concluding these considerations with state consolidation. He draws attention to the historical premises, dimensions of consolidation, its determinants, directions, time, measurement, state role, its processes and statehood. The study of consolidation is subjected to considerations as a science (p. 43), and its focus is first and foremost on the degree of institutionalization of the rules of systemic transformation (p. 51); as a phase in the evolution of a regime (p. 62); or as a phenomenon expressed by time, moment and rhythm (p. 64). Within the framework of consolidation, there are discussions on consolidated and non-consolidated democracies. The first can be defined as becoming routinized and assimilated in social, institutional or mental life (p. 44). The author rightly points out that a consolidated democracy is one that has "democratic citizens" (p. 66). On the other hand, the lack of consolidation, i.e. an unregistered democratic regime, is otherwise a defective regime (p. 53). It becomes a "dicto-democracy" in which the phenomenon of erosion of the system, which promotes the emergence of hybrids (p. 60).

Based on a number of theoretical categories, the author aptly points out that consolidation is the process that follows transformation (p. 45), and is the last stage of democracy (p. 49). This is the culmination of the process of change initiated (p. 48) which results in the inclusion of democratic values, the formation of a pro-democratic political culture and the achievement of progress. In such an arrangement of forces, a regime is defined as credible, and consolidated patterns of behavior and political behavior begin to function in a society (p. 47). All these activities have a positive dimension that is characterized by: structured variation (p. 50) or a progressive enlargement of procedures by an ever wider circle of political actors (p. 51). Consolidation can also take a negative dimension (p. 46), when it promotes specific groups of interests (p. 47) dominated by party leaders, clientelism and regional particularism, or "constitution without constitutionalism," which loses meaning as a reference to the political system (p. 56).

Consolidation is a multidimensional concept. It can be defined as a strengthening; as a process and a purpose; the victory of democratic political consciousness; a reflection on the moral condition of the elites (p. 46); as a theory of order and stability (p. 52); as institutionalization (p. 60); as deepening of state reforms, which consists in achieving the most advanced form of the system (p. 61); a time of change undermining the hitherto rules of the political game; a moment of deinstitutionalization in which the institutions of the previous regime are questioned (p. 41). Consolidation begins with the first parliamentary meeting of the first parliament elected in free elections (p. 72), but the establishment of democracy does not have to be the only possible goal of constitutional evolution (p. 39).

In the monograph, based on a number of definitions of consolidation, we are able to find an important consideration of the concept of transition $\leftrightarrow$ transformation. Transition is described by the author as a perfect process - as the transition from one particular stage of the political system to another (p. 39). Bartłomiej Zdaniuk, following Andrzej Antoszewski, stresses that this is the beginning of the dismantling of a specific political regime and the consolidation of the new regime (p. 42). He also cites the term present in the literature on the subject of "double transition," according to which the first "portion" of change tends to democracy and the other to consolidated democracy (p. 53). Sometimes this double transition becomes a complement to an unfinished transformation, during which "reserved domains" are eliminated (p. 61). Transformation, on the other hand, is an evolution from an authoritative authoritarian regime to an unknown one, which may be the reconstruction of the authoritarian regime (p. 40). Transition applies to time-limited activities, whereas transformation is a long-term process of institutionalizing a new system (p. 42), especially if it embraces the dimension of a democratic change.

The author clearly points out that "in the case of post-Soviet countries, it is difficult to talk about the transformation of the system and the consolidation of democracy, because of the weak- 
ness of the state framework" (p. 83). In the monograph, we can read that "in the case of postSoviet states, the problem lies primarily in the fact that, at the time of their creation, the borders of these countries did not coincide with the sense of national identity of the inhabitants" (p. 69), thus, in this case, consolidation becomes multi-level. Constitutional, representative, behavioral, or democratic consolidation of political culture (pp. 78-80) can be distinguished here. According to Bartłomiej Zdaniuk, "some Soviet countries may need to be examined for decolonization, ${ }^{2}$ because their characteristics are very similar to the problems faced by postcolonial African countries" (p. 40). Three basic dependencies can be identified: the problems of partial regimes that consolidate according to different rules and procedures (p. 58); various oligarchs, dominated by wealthy citizens with an anti-cultural reputation (p. 60); and also "bonded transactions" (p. 81) that have a significant impact on every political system.

In the context of the deliberations on state consolidation, the author points to the rather significant challenge of every transformation - transforming a "mobilized civil society" into an "institutionalized civil society" and breaking down the habits of the previous regime (p. 57). He also states that democracy does not need to have roots to be established, and that this process can take place in countries with different conditions (p. 39). The important thing is that the pace and direction of change are influenced by the actors functioning in political life (p. 41). Among the most important dimensions of consolidation are: territory, population and power (p. 89), and these issues subordinate further reflections.

In the next three chapters, Bartłomiej Zdaniuk highlights the specificity of territory, population and power, which in turn enables him to isolate the challenges facing the consolidation of the Republic of Moldova, and to formulate forecasts on the prospects for its development (p. 91).

In chapter II, entitled "Consolidation of the territory of the Republic of Moldova" (pp. 93-126), the issue of borders is discussed. The author refers to the issues of internal separatism: Gagauzian and Transnistrian, and also touches on the Ukrainian thread connected with the Transnistrian-Ukrainian border. On the basis of these considerations, he states that the territory of the Republic of Moldova totally fits into the theoretical schema of the consolidation indicated in the theoretical chapter, adding that it is a correlate of that process with respect to the state. Based on rich source material, the author argues that the main part of the territory of the Republic of Moldova is marked by tensions related to the identity and specificity of its population. Chapter III, entitled "Consolidation of the People of the Republic of Moldova" is devoted to Moldovan society (pp. 128-170). Here, the author touches on national and civic themes. He points at two dimensions: the ethno-political one and the state ambitions of the national community and civic political culture, as a political community governed by the people. In the area of considerations on national identity, the author asks numerous research questions, associated with the name of the state: the Republic of Moldova $\leftrightarrow$ Moldova $^{3}$ or the language: Moldovan $\leftrightarrow$ Romanian. These and other dilemmas of national identity lead to unequivocal claims that the population residing in the Republic of Moldova does not have a uniform ethnic background, because the nation is made up of citizens of different origins, including a large Russian population. The author concludes with clear statements that the Republic of Moldova is a state of 'ethniticization', in which the so-called Homo Moldovanus is a common attitude - a shy and passive citizen, without of a sense of competence, living in society characterized by a high level of economic emigration. Bartłomiej Zdaniuk emphasizes that the challenge for citizens of the

${ }^{2}$ See: Czachór, 2015.

${ }^{3}$ So far, in the literature on the subject, there has been no consideration of this subject. In her publication devoted to the party system of the Republic of Moldova (See: Sikora-Gaca, 2013), the author of this review very often uses the names Republic of Moldova $\leftrightarrow$ Moldova interchangeably. Bartłomiej Zdaniuk, by numerous historical-worldview correlations, clearly demonstrates that they are not identical. 
Republic of Moldova in the field of consolidation is a feeling of national pride, which, at this moment, is difficult to find in the society.

Chapter IV, entitled "Consolidation of the Republic of Moldova" (pp. 171-221), deals with aspects of the political game. The author discusses the experience and traditions of statehood in the Republic of Moldova. It indicates that the state apparatus is not being rebuilt, thus consolidating the rule of law is hampered by a deep-rooted Soviet heritage. Thus, he points to a rather significant problem which is often erroneously overlooked - the "social rejection of the law," which means the indifference of the inhabitants to norms and their functioning. A very negative phenomenon is the creation of a low-income social stratum, opposed by business elites. "At the time of the proclamation of the independence of the Republic of Moldova, and in the first years of its existence, the agronomists and managers of the kolkhoz, the so-called 'Green barons' [...], the nomenclature and the officers of the Secret Service succeeded in transforming political power into financial capital." From the very beginning of the existence of the independent state, continuity of political personnel has been developed which has contributed to the lack of unity of worldview and the diversity of the elites. The high degree of their social heterogeneity made the transformation process most dependent on the will of the ruling clans. Hence, it is clear that state consolidation depends to a great extent on the models of political elites. It is true that circulation within the elites is noticeable, but a change in the style of government does not give another dimension to the political game and maintains sociopolitical divisions for years. "Even the content of the constitutional provisions so far has not been a sufficient condition for the consolidation of the political system," or for any change in established attitudes and behaviors. As pointed out by the author - the deadlock in geopolitical identity leads to a deadlock of the party-personal arrangement, which in turn consolidates the stagnation and preserves the heterogeneous heritage of the country. In the shadow of the usurpation of power, the political parties are fighting for the survival of their networks, which only increases the level of social aggression and civil opposition on the one hand, and strengthens the position of political and business partners on the other. This political impasse makes any improvement in the area of the rule of law unfeasible. It is true that the international environment and its influence are an inherent part of shaping the state, but the lack of coherent developmental project for the Republic of Moldova has removed the prospect of consolidation of power in this political system.

In his monograph, Bartłomiej Zdaniuk presents numerous challenges to the consolidation of the state entity of the Republic of Moldova. He identifies this entity as a "geopolitical bastard," where the appropriation of political leadership leads to the alienation of civil society. He also refers to the phenomenon of "irresponsible pluralism" in which inefficient and corrupt elites distance citizens from the public sphere, emphasizing the phenomenon of political apathy. At the same time, he stresses that the future of consolidation depends on internal and external factors. The author gives the reader an extremely interesting publication where he presents a sprawling inconsistency, in which a weak state is faced with a weak society.

The premise of a review is that it should be critical. However, it is difficult to find faults in a publication of a uniformly high standard. This is so from the first pages of the monograph, where the preliminary questions are given (assumptions and hypotheses, the state of research, research methods and techniques), through all the subsequent chapters and annexes. The graphic presentations are also worth noting (pp. 233-243), including maps developed by Jakub Pieńkowski, which are extremely precise, accurate, substantive and comprehensible. It may be considered that, apart from the reliable analytical work of the Center for Eastern Studies (OSW), ${ }^{4}$ and that by Mr Kamil Całus, this paper is one of the more accurate studies on the Republic of Moldova in the Polish publishing market. In the opinion of the reviewer, the monograph should be translated into one of the congress languages as soon as possible.

\footnotetext{
${ }^{4}$ See: www.osw.waw.pl/.
} 


\section{Bibliography}

Solak J. (2009), Republika na trzy pęknięta. Historyczno-spoleczny, militarny i geopolityczny wymiar „zamrożonego konfliktu” o Naddniestrze, Europejskie Centrum Edukacyjne, Torun.

Oleksy P. (2016), Wspólnota z przypadku. Studium tożsamości mieszkańców Naddniestrza, Wydawnictwo Naukowe CONTACT/ABC, Gniezno.

Czachor R. (2015), Postradzieckie reżimy polityczne w perspektywie neopatrymonialnej. Wstep do badań, Fundacja Instytut Polsko-Rosyjski, Wrocław.

Sikora-Gaca M. (2013), System partyjny Mołdawii w latach 1989-2009, wydawnictwo TAKO, Toruń. www.osw.waw.pl/ (OSW/Center for Eastern Studies).

Małgorzata SIKORA-GACA

Koszalin University of Technology

Katarzyna DOMAGAŁA

University of Wrocław 
